\title{
Sistem Traceability untuk Mendukung Pengadaan Material requisition di PT Krakatau Engineering
}

\author{
Dimas Prasetyo dan Iwan Vanany \\ Jurusan Teknik Industri, Fakultas Teknologi Industri, Institut Teknologi Sepuluh Nopember (ITS) \\ Jl. Arief Rahman Hakim, Surabaya 60111 Indonesia \\ e-mail: vanany@ie.its.ac.id, prasetyo.dimasits@gmail.com
}

\begin{abstract}
Abstrak-Salah satu aspek yang penting dalam perencanaan proyek adalah proses pengadaan barang (procurement) untuk material proyek. Proses pengadaan barang berimplikasi langsung terhadap pengerjaan proyek terutama pada waktu penyelesaian suatu pekerjaan di proyek dikarenakan pekerjaan konstruksi baru akan dimulai jika material sudah tersedia di tempat. Aplikasi dari penggunaan teknologi informasi dalam manajemen proyek khususnya manajemen pengadaan material adalah traceability system yang menjadi alat krusial bagi sejumlah perusahaan dalam melakukan proses pelacakan material. Penelitian ini bertujuan untuk membuat sistem traceability yang terintegrasi mulai dari pembuatan material requisition kebutuhan material hingga material tiba di site area. Identifikasi aliran informasi dan proses bisnis kemudian terlebih dahulu dilakukan. Model yang digunakan dalam penelitian ini adalah unified modelling language sebagai model dasar arsitektur sistem traceability material proyek yang terdiri atas use case diagram, class diagram, dan sequence diagram untuk setiap pekerjaan pengadaan dan pengusutan material proyek yang kemudian diimplementaikan ke dalam bahasa pemrograman MySQL. Implementasi sistem traceability material proyek berupa software Material requisition Traceability System kemudian dilakukan proses validasi dan analisis manfaat. Manfaat dari penelitian ini dapat disimpulkan bahwa sistem traceability material proyek yang dirancang dapat diimplementasikan di setiap proyek PT Krakatau Engineering. Hal yang utama adalah sistem traceability material proyek mampu menjadi jembatan informasi antardepartemen yang menaungi pengadaan dan pengusutan material proyek.
\end{abstract}

Kata Kunci-Material Proyek, Nomor Material requisition, Sistem Traceability Material Proyek, Unified Modelling Language

\section{PENDAHULUAN}

$\mathrm{S}$ ALAH satu aspek yang penting dalam perencanaan proyek adalah proses pengadaan barang (procurement) untuk material proyek. Sistem pengadaan barang yang efektif merupakan hal yang kritis untuk project management karena mayoritas lebih dari 50 persen dari total project cost merupakan biaya untuk ketersediaan part, supplies, dan services procured [3]. Proses pengadaan barang berimplikasi langsung terhadap pengerjaan proyek terutama pada waktu penyelesaian suatu pekerjaan di proyek dikarenakan pekerjaan konstruksi baru akan dimulai jika material sudah tersedia di tempat.

Proses input kebutuhan material khususnya pada suatu proyek harus ditunjang dengan perencanaan material requisition yang terstruktur dan terencana. Material requisition merupakan suatu dokumen yang mengindikasikan demand material yang harus dipenuhi. Proses perencanaan material requisition mampu mengidentifikasi kebutuhan material, kuantitas yang diperlukan, dan tanggal material dibutuhkan. Secara manual, proses material requisition akan dicetak dan dikirim ke departemen purchasing. Proses perencanaan material requisition yang lebih terotomasi dapat disimpan dalam database ERP yang secara otomatis diteruskan ke dalam database perusahaan. Setelah material requisition terimplementasi dalam purchase requisition, penentuan supplier harus ditentukan dan dipilih. Proses penentuan supplier dapat menjadi kompleks karena terdiri atas proses meminta keterangan, permintaan quotation, negosiasi dan lainlain. Selanjutnya, purchase requisition yang sudah lengkap dikirim ke bagian purchasing department untuk dibuat purchase order.

Proses untuk pengerjaan konstruksi menunggu kedatangan dari material yang sudah dipesan dalam purchase order. Ketika material sudah datang ke proyek, departemen warehouse menerima material dan menyimpan di warehouse utama. Jika tidak ada masalah dari proses shipment, material kemudian disimpan dan dokumen dari penerimaan barang dibuat. Namun, jika terjadi defect maka material yang terkena defect akan diminta verifikasi oleh pihak supplier maupun akan dibenahi sendiri oleh pihak kontraktor. Pengerjaan proyek konstruksi kemudian dapat dijalankan ketika material untuk tiap site pada proyek tersuplai dengan baik.

Aplikasi dari penggunaan teknologi informasi dalam manajemen proyek khususnya manajemen pengadaan material adalah traceability system yang menjadi alat krusial bagi sejumlah perusahaan dalam melakukan proses pelacakan material. Traceability system juga bertujuan untuk meningkatkan keamanan serta keefektivitas pada proses pengadaan material. Aung dan Chang [1] berpendapat bahwa traceability system yang baik mampu meminimasi kualitas material yang kurang baik dan tidak aman dalam rangkaian supply chain. Khusus pada pengerjaan di suatu proyek, menurut [2] traceability system memiliki sejumlah manfaat diantaranya: change impact analysis, product conformance, process compliance, project accountability, baseline reproduceability, dan organizational learning.

Teknologi identifikasi terotomasi dapat digunakan untuk meminimalisasi terjadinya kesalahan manusia pada proses pengadaan barang. Pada penelitiannya mengenai traceability sysem untuk darah disebutkan bahwa dengan adanya teknologi tersebut sistem traceability secara total dari proses pengadaan barang khususnya darah dapat dicapai. Teknologi ini juga dapat 
meningkatkan keamanan pada proses pengadaan barang, mengurangi biaya dengan adanya monitoring, dan kontrol material dengan menggunakan aliran informasi yang kontinyu antara departemen yang berkaitan. Secara integratif, traceability system mampu mendukung proses pengadaan material requisition secara utuh mulai dari input daftar material yang dibutuhkan dalam keperluan proyek sampai memastikan datangnya material pada area proyek.

PT Krakatau Engineering sebagai salah satu anak perusahaan yang dimiliki oleh PT Krakatau Steel Persero Tbk merupakan perusahaan yang bergerak di bidang EPC (Engineering, Procurement, and Construction). PT Krakatau Engineering berfokus di bidang konstruksi dan engineering yang menyediakan jasa rekayasa (shop drawing), pengadaan barang, pemasangan dan commissioning, uji coba daya guna dan startup, pembangunan fasilitas, dan jasa supervise.

Adanya miss trace antara data material requisition dari engineering dan data kelengkapan material di tiap area menimbulkan berbagai masalah. Proses identifikasi dari material pipa untuk setiap area dilakukan secara manual dan tidak terotomatisasi sehingga adanya miss trace material membuat material pipa yang datang bercampur dengan area lain. Hal ini menjadikan sulitnya antisipasi proses pelacakan keberadaan pipa di tiap area yang ada. Hal ini menimbulkan masalah yang kompleks mengingat suplai material berimplikasi kepada proses konstruksi. Masalah kuantitas dan ketersediaan material untuk tiap area merupakan masalah yang serius dalam pengerjaan proyek ini mengingat semua area pada proyek ini tersambung dan terintegrasi.

Proses input kebutuhan material dan penelusuran untuk tiap material pada PT Krakatau Engineering secara penuh dilakukan dengan cara manual sehingga material terpartisi sendiri-sendiri pada tiap area. Hal ini berimplikasi kepada sulitnya mengintegrasikan kebutuhan material dalam satu database sehingga data kebutuhan material tidak dapat terakomodasi secara menyeluruh. Proses penelusuran material pun juga dilakukan secara manual sehingga kemungkinan miss trace akibat human error, pencatatan proses di tiap departemen, dan akibat dari penumpukan material pipa akibat proses penelusuran material yang tidak terotomasi menjadi sangat besar.

Adanya masalah pada proses penelusuran material dalam di PT Krakatau Engineering khususnya di proyek Blast Furnace ini sehingga penelitian ini akan mengkaji proses pengadaan dan pembuatan material requisition serta traceability untuk PT Krakatau Engineering. Penelitian ini berfokus kepada pembuatan perencanaan sistem informasi yang mampu mengakomodasi pembuatan material requisition yang integratif hingga perencanaan traceability system yang mampu melacak material di tiap area secara otomatis. Hasil penelitian ini diharapkan menjadi peringatan dini program/proyek sehingga manajer dapat mengidentifikasi dan mengendalikan masalah sebelum terjadi penyimpangan lebih lanjut pada proyek khususnya dalam hal proses pengadaan barang.

\section{METODE PENELITIAN}

Proses pemetaan proses bisnis dan alur informasi merupakan aktivitas utama dalam mengembangkan pembuatan sistem informasi untuk kepentingan traceability system untuk kepentingan penelusuran dan pengendalian kualitas material. Penulis mengembangkan business process untuk traceability system berdasarkan interview dengan divisi procurement dan project manager Proyek Blast Furnace. Informasi mengenai alur informasi juga diidentifikasi menggunakan observasi dan interview dengan para staf beserta dokumen untuk tiap departemen.

Pengolahan data terdiri atas konsep sistem traceability material dan penentuan letak titik penelusuran. Sistem ini dibagi menjadi dua subsistem yang terdiri atas traceability system dan database server.
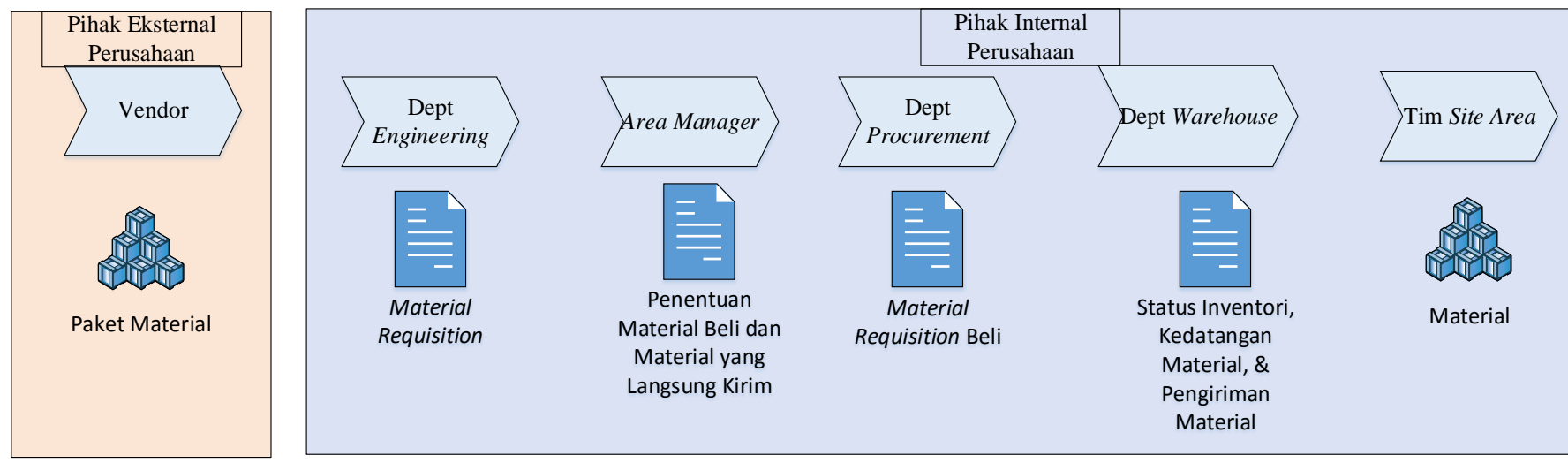

Gambar 1 Aliran material di PT Krakatau Engineering 


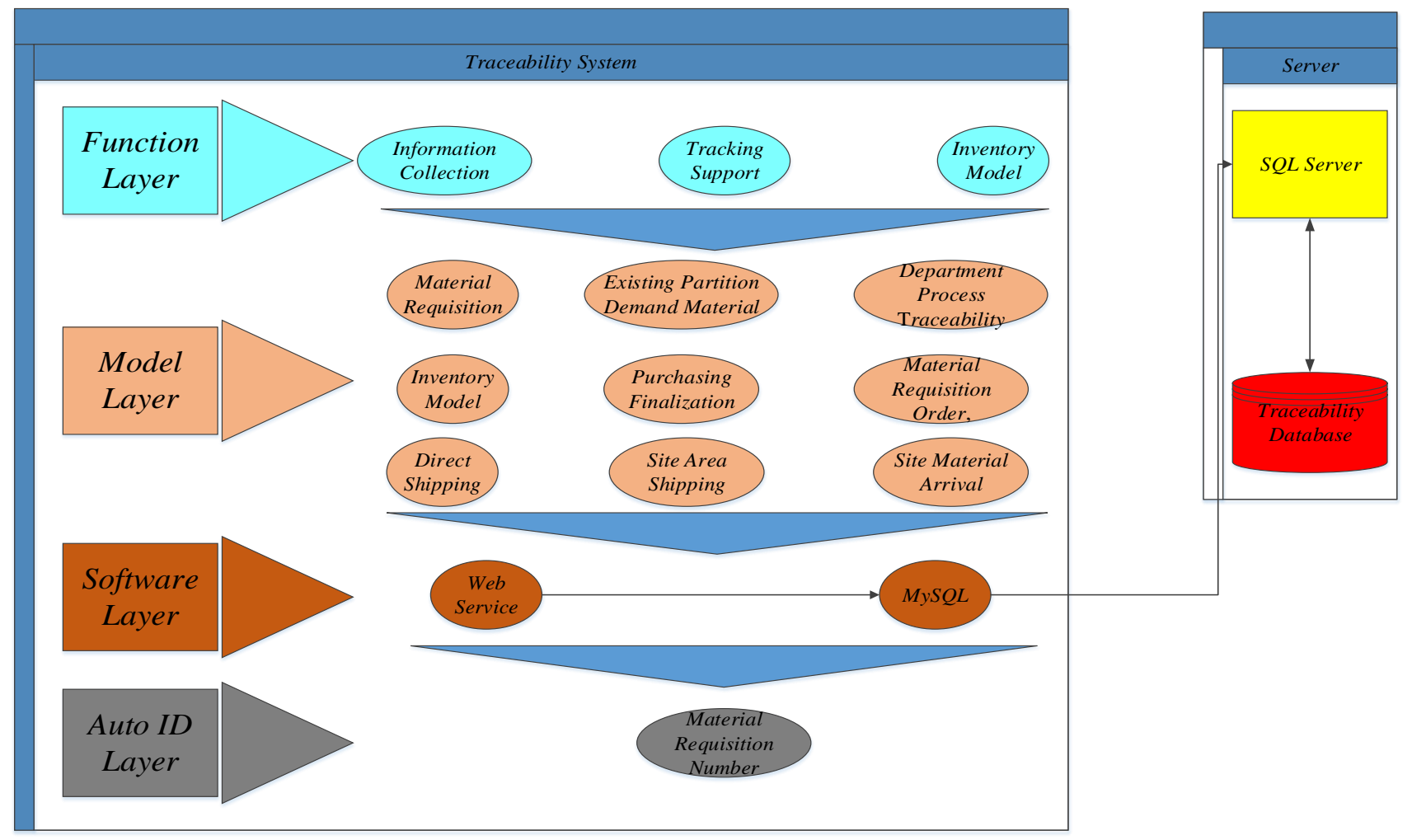

Gambar 2 Rancangan sistem traceability material proyek

\section{Input Data}

Proses pemetaan proses bisnis dan alur informasi merupakan aktivitas utama dalam mengembangkan pembuatan sistem informasi untuk kepentingan traceability system untuk kepentingan penelusuran dan pengendalian kualitas material. Penulis mengembangkan business process untuk traceability system berdasarkan interview dengan divisi procurement dan project manager Proyek Blast Furnace

2. Pengolahan Data

Model yang menjadi acuan untuk pembuatan sistem traceability terdiri atas model untuk proses pembuatan material requisition (material requisition), model partisi kebutuhan material existing di proyek untuk proses persetujuan material requisition (existing partition demand material), model penelusuran proses antardepartemen untuk proses penelusuran material requisition (department process traceability), model evaluasi material yang ada di warehouse untuk proses lihat inventaris (inventory model), model finalisasi pembelian material (purchasing finalization), model dokumentasi mengenai laporan kedatangan material dari vendor (material requisition order), model pengiriman material siap kirim (direct shipping) model pengiriman material ke tiap site area (site area shipping), serta model penerimaan material yang sudah diterima di tiap site area dan siap untuk dilakukan proses konstruksi (site material arrival).

3. Perancangan Aliran Informasi dan Aliran Proses Antardepartemen

Pada tahap ini deskripsi dari model dan letak titik penelusuran kemudian diimplementasikan ke dalam rancangan aliran informasi dan aliran proses antardepartemen.
4. Perancangan Data Informasi yang Disimpan

Pada tahap ini akan ditentukan inputan informasi apa yang nantinya akan disimpan dalam sistem traceability material proyek.

5. Perancangan Rangkaian Penomoran Aliran Material Proyek Pada tahap ini akan ditentukan rangkaian penomoran aliran material proyek untuk proses identifikasi tiap departemen yang menaungi pekerjaan pengadaan dan pengusutan material.

6. Perancangan Use Case Diagram

Perancangan use case diagram digunakan untuk menunjukkan proses-proses yang ada di dalam sistem traceability material dalam sistem traceability material proyek oleh masing-masing para stakeholder pengadaan material proyek.

7. Perancangan Class Diagram

Class Diagram menunjukkan bagian-bagian dari orientasi objektif suatu sistem. Konsep ini bertujuan untuk menggambarkan hubungan antarentitas yang berbeda-beda yang berkenaan mengenai hubungan antara kelas-kelas dan interface suatu subsistem.

8. Perancangan Sequence Diagram

Perancangan sequence diagram ini akan dibuat beberapa diagram yakni pada implementasi proses yang dilakukan di tiap objek amatan.

9. Uji Coba Perangkat Lunak

Pada tahap ini akan dilakukan uji coba terhadap perangkat lunak yang telah dibuat. Proses penelusuran dapat dinilai performansinya sehingga dapat dinilai apakah perangkat lunak yang dibuat baik ataupun terdapat kendala pada penggunaannya. 


\section{PENGUMPULAN DAN PENGOLAHAN DATA}

\section{A. Perancangan Aliran Informasi dan Aliran Proses Antardepartemen}

Pada subbab ini akan dijelaskan mengenai aliran informasi dan aliran proses antardepartemen untuk perancangan awal sistem traceability material proyek berupa Software Material requisition Traceability System. Aliran informasi dan proses antardepartemen akan dijelaskan lebih rinci untuk mengidentfikasi proses yang akan dirancang dalam pembuatan sistem traceability material proyek.

- Perancangan Aliran Informasi dan Aliran Proses Departemen Engineering

Peran karyawan departemen engineering khususnya untuk pengadaan dan pengusutan material adalah membuat daftar material requisition. Karyawan departemen ini mempartisi kebutuhan material dari gambar rancangan yang dibuat oleh arsitek dari karyawan internal divisi ini yang kemudian disusunlah material requisition sebagai acuan daftar beli material.

Pilihan site area terlebih dahulu ditentukan pada pembuatan material requisition. Tenggat waktu konstruksi kemudian ditentukan oeh karyawan departemen engineering. Hal selanjutnya yang dilakukan oleh karyawan departemen engineering adalah identifikasi pekerjaan yang membutuhkan suplai material. Karyawan departemen engineering kemudian mengidentifikasi kebutuhan material berdasarkan jenis material, spesifikasi material, dan bahan material. Jumlah material yang dibutuhkan kemudian ditentukan dan diakhiri dengan mencetak material requisition.

- Perancangan Aliran Informasi dan Aliran Proses Area Manager

Peran area manager khususnya untuk pengadaan dan pengusutan material adalah membuat persetujuan permintaan material sesuai dengan kebutuhan yang terimplikasi dari material requisition. Area manager terlebih dahulu mengecek daftar material yang telah dibuat oleh departemen engineering dikarenakan area manager harus mengkoordinasikan segala sumber daya yang ada di proyek serta jadwal pelaksanaan pembangunan suatu bangunan di tiap site area. Proses selanjutnya adalah area manager melakukan persetujuan material dengan memilih material requisition dan melakukan pemilihan tiga kelompok material untuk material requisition tersebut. Kelompok material itu adalah kelompok material yang siap kirim ke tiap site area yang mana kelompok material ini merupakan kelompok material yang tersedia di warehouse, kelompok material siap beli yang mana kelompok material ini merupakan kelompok material yang tidak tersedia di warehouse dan harus dilakukan proses pembelian, dan kelompok material yang tersedia di warehouse, tetapi tidak mencukupi kebutuhan untuk satu material requisition. Area manager kemudian melakukan proses finalisasi persetujuan. Proses yang dapat dilakukan oleh area manager selanjutnya adalah mengkover penelusuran material dan proses antardepartemen. Status inventaris yang ada di gudang juga dapat dikover oleh area manager.
- Perancangan Aliran Informasi dan Aliran Proses Departemen Procurement

Peran departemen procurement khususnya untuk pengadaan dan pengusutan material adalah melakukan proses finalisasi pembelian material. Departemen procurement menerima material requisition beli yang sebelumnya dibuat dan disetujui oleh area manager. Proses selanjutnya yang dikerjakan oleh departemen ini adalah membuat rencana pengadaan material berdasarkan kebutuhan material dalam material requisition beli. Proses purchasing material yang melibatkan banyak proses tidak dikover dalam cakupan pengerjaan tugas akhir ini. Departemen procurement kemudian melakukan proses finalisasi pembelian material.

- Perancangan Aliran Informasi dan Aliran Proses Departemen Warehouse

Peran departemen warehouse khususnya untuk pengadaan dan pengusutan material adalah melakukan pekerjaan penerimaan dan penyimpanan material serta inisiasi pengiriman material ke tiap site area. Departemen warehouse terlebih dahulu menerima informasi mengenai kebutuhan material dari area manager dan departemen procurement. Informasi dari area manager mengindikasikan material yang tersedia di warehouse sehingga para karyawan departemen ini melakukan pengecekan ketersediaan material yang dilanjutkan proses inisiasi pengiriman material ke tiap site area. Informasi dari departemen procurement mengindikasikan material yang telah dilakukan proses pembelian yang ketersediaannya disuplai oleh pihak vendor. Material yang sudah datang kemudian diterima dan dicatat kuantitasnya. Material kemudian disimpan di warehouse. Karyawan departemen warehouse mengintegrasikan material yang ada di warehouse untuk kemudian memproses pengiriman ke tiap site area.

- Perancangan Aliran Informasi dan Aliran Proses Tim Site Area

Proses di site area merupakan proses paling akhir mengenai pengadaan material di PT Krakatau Engineering. Material yang dikirim dari warehouse kemudian diterima di tiap site area. Material yang telah sampai di site area kemudian dicatat kedatangannya dan kemudian dilakukan proses konstruksi.

\section{PERANCANGAN SISTEM TRACEABILITY MATERIAL PROYEK}

Segala aktivitas yang dilakukan oleh karyawan departemen engineering kemudian diimplementasikan dalam use case diagram bagi pekerjaan pengadaan material di PT Krakatau Engineering: 

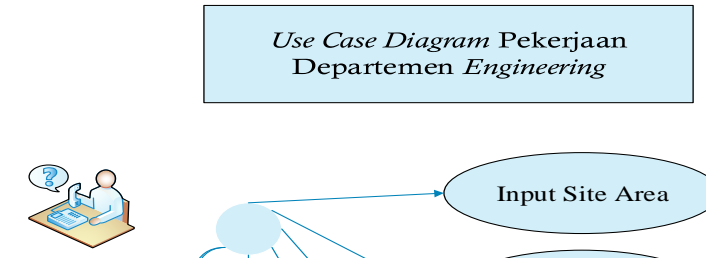

Departemen Engineering

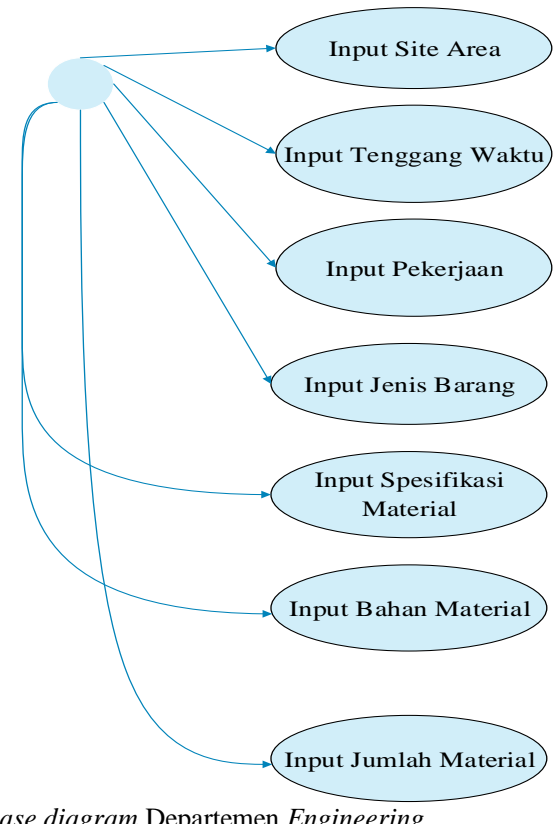

Gambar 3Use case diagram Departemen Engineering

Segala aktivitas yang dilakukan oleh area manager kemudian diimplementasikan dalam use case diagram bagi pekerjaan pengadaan material di PT Krakatau Engineering:

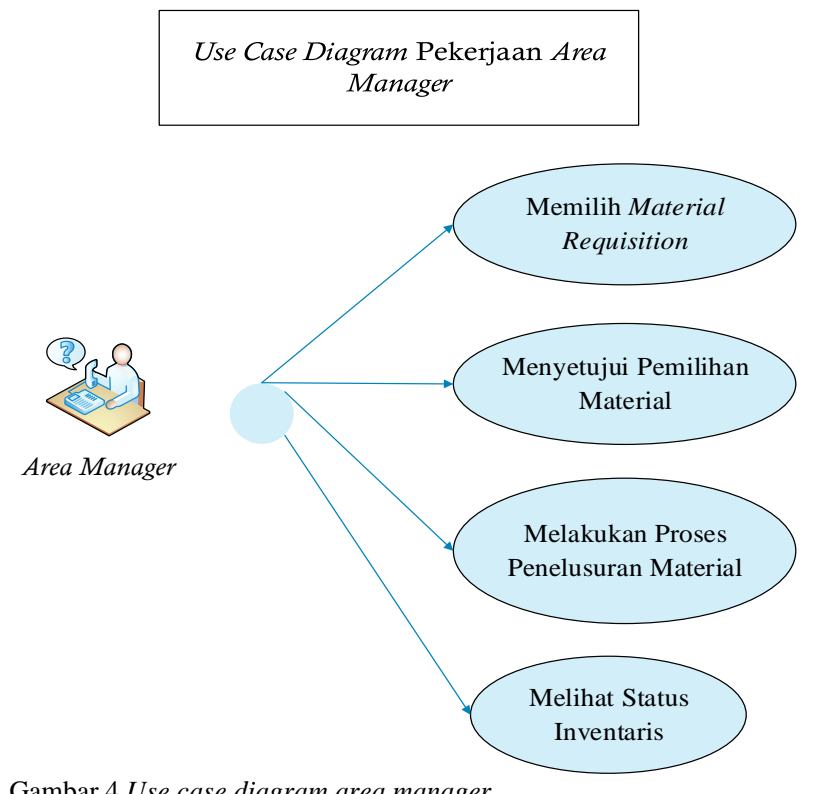

Gambar 4 Use case diagram area manager

Segala aktivitas yang dilakukan oleh karyawan departemen procurement kemudian diimplementasikan dalam use case diagram bagi pekerjaan pengadaan material di PT Krakatau Engineering:
Use Case Diagram Pekerjaan Departemen Procurement

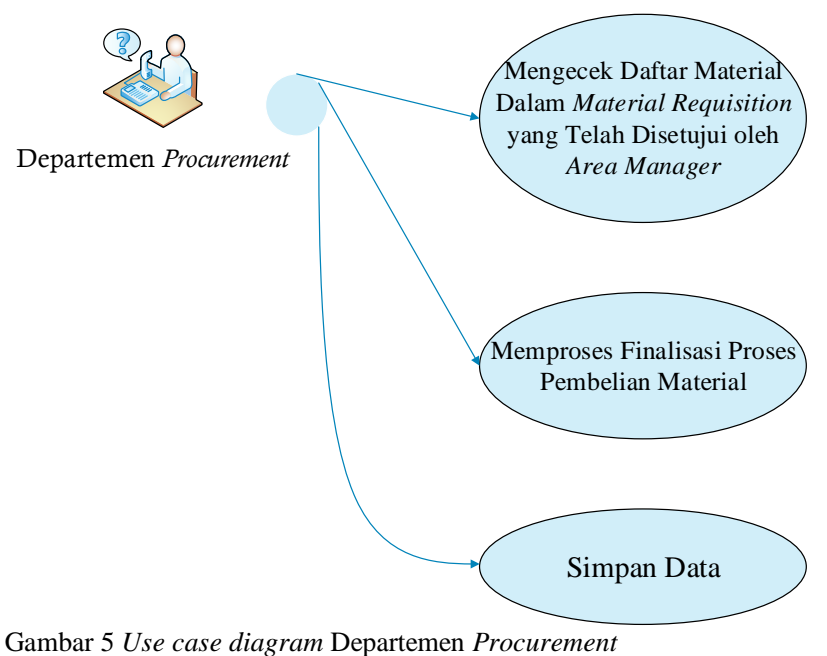

Segala aktivitas yang dilakukan oleh karyawan departemen quality control \& warehouse utama kemudian diimplementasikan dalam use case diagram bagi pekerjaan pengadaan material di PT Krakatau Engineering:

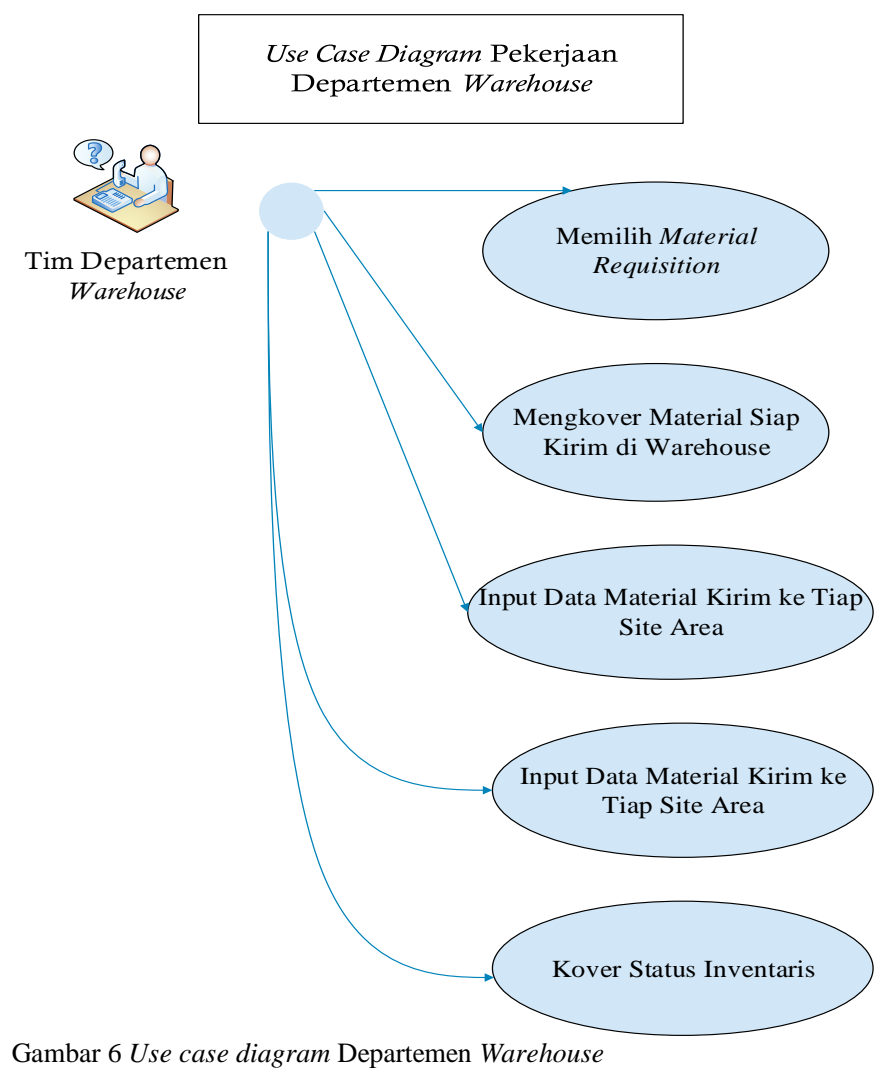

Segala aktivitas yang dilakukan oleh karyawan tim site area kemudian diimplementasikan dalam use case diagram bagi pekerjaan pengadaan material di PT Krakatau Engineering: 


\section{Use Case Diagram Tim Site Area}

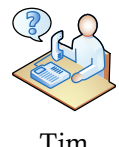

Tim Expediting

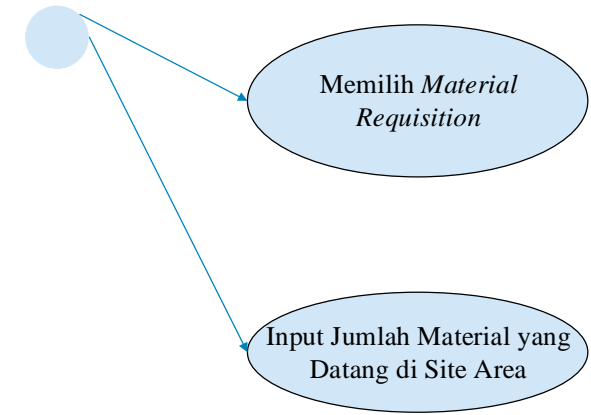

Gambar 7 Use Case Diagram Tim Site Area

\section{UJI COBA PERANGKAT LUNAK DAN ANALISIS SISTEM TRACEABILITY MATERIAL PROYEK}

Validasi sistem traceability material proyek dilakukan setelah implementasi dari rancangan keseluruhan sistem traceability material proyek berupa Software Material requisition Traceability System diujicoba oleh pihak yang menaungi pekerjaan pengadaan dan pengusutan material di PT Krakatau Engineering. Validasi dilakukan dengan memberikan kuesioner kepada para user dan para pemangku kebijakan pengadaan dan pengusutan material mulai dari pembuatan material requisition hingga material sampai di tiap site area proyek. Kuosioner diberikan setelah dilakukan ujicoba Software Material requisition Traceability System. Kuesioner validasi untuk PT Krakatau Engineering terdiri atas tiga kelompok pertanyaan yaitu kelompok pertanyaan desain proses bisnis, kelompok pertanyaan kegunaan sistem traceability material proyek, dan kelompok pertanyaan manfaat sistem traceability material proyek.

- Analisis Manfaat Sistem Traceability Material Proyek

Sistem traceability material proyek dirancang untuk digunakan oleh beberapa pihak yang terlibat dalam proses pengadaan dan pengusutan material yang terdiri atas departemen engineering, area manager, departemen procurement, departemen warehouse, dan tim site area. Selain dilakukan analisis kuosioner hal yang perlu dilakukan adalah menganalisis manfaat sistem traceability material proyek. Analisis manfaat ini dapat diketahui sejumlah benefit apa saja yang dapat diperoleh dengan mengimplementasikan secara penuh sistem traceability material proyek berupa Software Material requisition Traceability System.

Sistem traceability memungkinkan untuk akurasi, efisiensi, dan penyimpanan data material pada rantai pasok dengan tujuan untuk meminimalisasi biaya operasional dan meningkatkan keuntungan. Berdasarkan penelitian disebutkan bahwa tiga sampai empat perusahaan percaya bahwa sistem traceability penting dan layak digunakan. Selain itu, manfaat yang diperoleh dari implementasi sistem traceability ialah perbaikan operasi kerja seperti perbaikan kecepatan dan efisiensi dalam hal inventory management dan product handling, serta kemudahan pelacakan dalam rantai pasok.
Manfaat yang berkaitan dengan implementasi traceability dapat dikategorikan menjadi empat yaitu pengaturan dan pengawasan (regulatory benefits), respon pasar dan konsumen (market \& customer respons), manajemen penarikan dan risiko (recall and risk management), serta keuntungan rantai pasok (supply chain benefits). Berdasarkan empat kategori tersebut, akan dilakukan analisis manfaat terhadap sistem traceability material yang nantinya akan diimplementasikan secara penuh oleh PT Krakatau Engineering.

- Analisis Biaya Implementasi Sistem Traceability Material Proyek

Analisis biaya dilakukan untuk mengetahui apakah ada kemanfaatan dari segi biaya yang dilakukan dengan implementasi sistem yang telah dirancang. Biaya yang dimaksud adalah sejumlah uang yang diinvestasikan untuk menunjang sistem yang kemudian di analisis mengenai keuntungan yang didapatkan dengan mengimplementasikan sistem ini secara keseluruhan. Tabel berikut merupakan daftar peralatan pendukung sistem traceability material proyek.

Tabel 1

Peralatan pendukung sistem traceability proyek

\begin{tabular}{|c|c|c|c|c|c|c|}
\hline $\begin{array}{l}\mathrm{N} \\
\mathrm{o}\end{array}$ & Alat & $\begin{array}{c}\mathrm{Ju} \\
\mathrm{mla} \\
\mathrm{h} \\
\end{array}$ & $\begin{array}{l}\text { Nama } \\
\text { Barang }\end{array}$ & $\begin{array}{l}\text { Harga } \\
\text { Satuan }\end{array}$ & $\begin{array}{c}\text { Total Biaya } \\
\text { dengan Komputer }\end{array}$ & $\begin{array}{c}\text { Total Biaya } \\
\text { tanpa Komputer }\end{array}$ \\
\hline 1 & $\begin{array}{c}\text { Kompu } \\
\text { ter }\end{array}$ & 20 & $\begin{array}{c}\text { Asus } \\
\text { Desktop } \\
\text { M32AD- } \\
\text { ID008D }\end{array}$ & $\begin{array}{c}\mathrm{Rp} \\
5.199 .000 \\
,-\end{array}$ & $\frac{\mathrm{Rp}}{103.980 .000,-}$ & Rp 0,- \\
\hline 2 & Printer & 3 & $\begin{array}{c}\text { Canon } \\
\text { Multifunct } \\
\text { ion Inkjet } \\
\text { Printer } \\
\text { MX497 }\end{array}$ & $\begin{array}{c}\mathrm{Rp} \\
1.375 .000 \\
\text {,- }\end{array}$ & Rp 4.125.000,- & $\begin{array}{c}\mathrm{Rp} \\
4.125 .000,-\end{array}$ \\
\hline 3 & $\begin{array}{c}\text { Wi-fi } \\
\text { Router }\end{array}$ & $\begin{array}{l}3 \\
\text { Tot }\end{array}$ & $\begin{array}{c}2,4 \mathrm{G} \\
\text { 150MBPS } \\
\text { Wifi } \\
\text { Modem } \\
\text { Router } \\
\text { Investasi }\end{array}$ & $\begin{array}{c}\mathrm{Rp} \\
318.000,-\end{array}$ & Rp 954.000,- & Rp 954.000,- \\
\hline
\end{tabular}

Hal selanjutnya yang dilakukan adalah mencari biaya yang mengakomodasi penunjang lainnya yaitu biaya investasi dan biaya perancangan web dan hosting. Total dari kedua komponen biaya ini adalah sebagai berikut:

Tabel 2

Komponen biaya

\begin{tabular}{clcc}
\hline \hline No & \multicolumn{1}{c}{ Komponen Biaya } & $\begin{array}{c}\text { Total Biaya } \\
\text { dengan } \\
\text { Komputer }\end{array}$ & $\begin{array}{c}\text { Total Biaya } \\
\text { tanpa Komputer }\end{array}$ \\
\hline 1 & $\begin{array}{l}\text { Biaya Investasi } \\
\text { Biaya Perancangan } \\
\text { dan Hosting } \\
\text { Jumlah Biaya }\end{array}$ & $\begin{array}{c}\text { Rp 109.059.000,- } \\
\text { Rp 35.000.000,- }\end{array}$ & $\begin{array}{c}\text { Rp 5.079.000,-- } \\
\text { Rp 35.000.000,- }\end{array}$ \\
& Rp 144.059.000,- & Rp 40.079.000,- \\
\hline \hline
\end{tabular}

Perancangan sistem traceability material proyek memiliki manfaat sebagai jembatan informasi antardepartemen yang terlibat dalam pengadaan dan pengusutan material. Sistem ini juga bermanfaat untuk meminimalisasi terjadinya kesalahan proses distribusi maupun proses ketersediaan material di warehouse. Oleh karena itu, kepastian tiap material proyek sampai ke site area sangatlah diperlukan. Persentase kesalahan dalam proses pengadaan material juga diperhatikan untuk memperkuat analisis biaya. Persentase diidentifikasi melalui tanya jawab pada pihak yang berkaitan dan didapat kesimpulan bahwa akibat dari sistem pengadaan material yang tidak 
terintegrasi dan terotomatisasi mengakibatkan muncul potensi loss sebesar 30\%. Benefit lainnya akibat dari pengimplementasian sistem pengadaan dan pengusutan material yang terotomatisasi adalah mengurangi material proyek recall dan mengurangi biaya pengiriman material untuk sekali pengadaan. Tabel berikut mengindikasikan sejumlah benefit yang didapat dari implementasi sistem pengadaan dan pengusutan material proyek yang terotomatisasi:

Tabel 3

Tabel Benefit

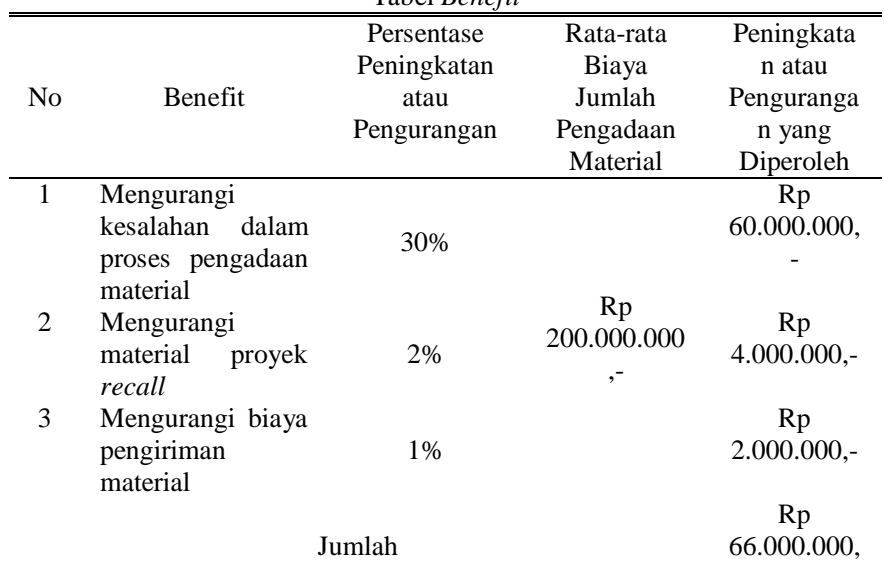

Benefit Cost Ratio (BCR) digunakan untuk melakukan analisis kelayakan penerapan sistem pengadaan dan pengusutan material proyek yang terotomatisasi. Nilai dari BCR dapat dihitung dengan rumus berikut [4].

$B C R=\frac{\text { Manfaat Ekuivalen }}{\text { Ongkos Ekuivalen }}$

\section{Dimana:}

BCR: Manfaat Ekuivalen/Ongkos Ekuivalen

Manfaat Ekuivalen: seluruh manfaat setelah dikurangi dengan dampak negatif yang dinyatakan dalam nilai mata uang.

Ongkos Ekuivalen: semua ongkos setelah dikurangi dengan besarnya penghematan.

Benefit merupakan manfaat yang diperoleh dari penerapan sistem pengadaan dan penulusuran material yang terotomatisasi yang dikonversikan dengan nilai mata uang. Komponen benefit yang pertama adalah pengurangan biaya akibat kesalahan dalam proses pengadaan material. Pengurangan biaya ini didapat dari akumulasi persentase kesalahan pengadaan material yang mencapai $30 \%$ untuk sekali pengadaan material yang berkisar Rp 200.000.000,- sehingga potensi penghematan dari minimalisasi kesalahan dalam pengadaan material berkisar Rp 60.000.000.000,-. Komponen benefit yang kedua adalah pengurangan material proyek yang mengalami recall akibat kesalahan inputan kebutuhan material dan kualitas material yang mencapai $2 \%$ untuk sekali pengadaan material yang berkisar Rp 200.000.000,- sehingga potensi penghematan dari minimalisasi kesalahan ini adalah berkisar Rp 4.000.000,-. Komponen benefit yang ketiga adalah pengurangan biaya pengiriman material akibat suplai material yang berlebih atau berkurang yang mencapai $1 \%$ dari total biaya tonase pengiriman material sehingga potensi penghematan dari minimalisasi kesalahan ini adalah Rp2.000.000,-.
Nilai kompensasi akibat biaya operasional dan perawatan asset berupa komputer juga dimasukkan dalam komponen biaya. Biaya operasional ini mencakup biaya perbaikan jika komputer yang dimiliki tiap departemen mengalami kerusakan. Nilai kompensasi dihitung dari $1 \%$ dari nilai investasi untuk jenis investasi tanpa pembelian komputer sehingga diperoleh nilai 1\% x Rp66.000.000,- yaitu sama dengan Rp660.000,-.

Nilai koefisien BCR dapat diperoleh dengan menggunakan tingkat suku bunga per tahun yang berkisar $11 \%$ dan sistem traceability material proyek direncanakan untuk jangka waktu lima tahun maka diperoleh nilai BCR sebagai berikut:

\begin{tabular}{|c|c|c|c|c|}
\hline \multicolumn{5}{|c|}{$\begin{array}{c}\text { Tabel } 4 \\
\text { Benefit Cost Ratio }\end{array}$} \\
\hline No & Jenis Investasi & $\begin{array}{l}\text { Nilai } \\
\text { Benefit }\end{array}$ & $\begin{array}{c}\text { Nilai } \\
\text { Kompensasi }\end{array}$ & $\begin{array}{c}\text { Nilai } \\
\text { Investasi } \\
\text { Total } \\
\end{array}$ \\
\hline 1 & $\begin{array}{l}\text { Dengan } \\
\text { pembelian } \\
\text { komputer }\end{array}$ & $\begin{array}{c}\mathrm{Rp} \\
66.000 .000,-\end{array}$ & - & $\begin{array}{c}\mathrm{Rp} \\
144.059 .000,\end{array}$ \\
\hline 2 & $\begin{array}{l}\text { Tanpa pembelian } \\
\text { komputer }\end{array}$ & $\begin{array}{c}\mathrm{Rp} \\
\text { 66.000.000,- } \\
\text { Benefit Cost Rati }\end{array}$ & $\begin{array}{l}\text { Rp 660.000,- } \\
(\mathrm{BCR})\end{array}$ & $\begin{array}{c}\mathrm{Rp} \\
40.079 .000,-\end{array}$ \\
\hline No & Jenis Investasi & $\begin{array}{c}\text { Nilai } \\
\text { Benefit }\end{array}$ & $\begin{array}{c}\text { Nilai } \\
\text { Investasi } \\
(\mathrm{A} \mid \mathrm{P}, 11 \% 5)\end{array}$ & B/C Ratio \\
\hline 1 & $\begin{array}{l}\text { Dengan } \\
\text { pembelian } \\
\text { komputer }\end{array}$ & $\begin{array}{c}\mathrm{Rp} \\
66.000 .000,-\end{array}$ & $\begin{array}{c}\mathrm{Rp} \\
38.978 .043,63\end{array}$ & 1,693260971 \\
\hline 2 & $\begin{array}{l}\text { Tanpa pembelian } \\
\text { komputer }\end{array}$ & $\begin{array}{c}\mathrm{Rp} \\
65.340 .000,-\end{array}$ & $\begin{array}{c}\mathrm{Rp} \\
10.844 .175,03\end{array}$ & 6,025354609 \\
\hline
\end{tabular}

Tabel diatas menunjukkan hasil perhitungan Benefit Cost Ratio untuk sistem pengadaan dan penelusuran material proyek. Penghitungan nilai koefisien Benefit Cost Ratio adalah mencari nilai annual dari nilai investasi. Faktor pengali yang digunakan dalam perhitungan nilai annual investasi adalah $(\mathrm{A} \mid \mathrm{P}, 11 \%, 5)$ yang artinya adalah dicari annual dari nilai present $(\mathrm{P})$ yang diketahui dengan tingkat suku bunga $11 \%$ dan dalam jangka waktu lima tahun. Nilai factor pengali didapat dari tabel pemajemukan diskrit untuk $(\mathrm{A} \mid \mathrm{P}, 11 \%, 5)$ diperoleh nilai 0.27057 sehingga nilai investasi апnual untuk investasi dengan pembelian komputer misalnya diperoleh dengan cara Rp144.059.000,00 x 0.27057 = Rp 38.978.043,63 Berdasarkan hasil perhitungan BCR seperti Tabel 4 diperoleh nilai BCR $>1$ yaitu $\mathrm{BCR}=1,69$ untuk investasi dengan pembelian komputer dan $\mathrm{BCR}=6.025$ untuk investasi tanpa pembelian komputer.

Perancangan sistem traceability material proyek pada penelitian ini yang secara aplikatif berupa Software Material requisition Traceability System merupakan representasi dari proses bisnis pada objek amatan PT Krakatau Engineering yang merupakan salah satu perusahaan yang bergerak di bidang engineering, procurement, dan construction. Konsep awal sistem traceability khusus untuk material proyek ini adalah membangun rancangan awal dan model traceability yang akan dipakai di PT Krakatau Engineering. Rancangan sistem traceability ini mampu merepresentasikan sumber data yang digunakan, arah arus informasi, penyimpanan data, dan sejumlah transformasi yang berkaitan dengan proses kerja yang ada dalam pengadaan material di PT Krakatau Engineering. Rancangan yang ada kemudian diimplementasikan ke dalam rancangan titik penelusuran material yang terimplementasi melalui aliran proses kerja dan informasi tiap elemen pelaku 
pengadaan dan pengusutan material di PT Krakatau Engineering yang terdiri atas departemen engineering, area manager, departemen procurement, departemen warehouse, dan tim site area.

\section{KESIMPULAN}

Berikut merupakan beberapa kesimpulan yang dapat diambil dalam penelitian ini, antara lain:

1. Perancangan sistem traceability material proyek pada penelitian ini yang secara aplikatif berupa Software Material requisition Traceability System merupakan representasi dari proses bisnis pada objek amatan PT Krakatau Engineering yang merupakan salah satu perusahaan yang bergerak di bidang engineering, procurement, dan construction. Konsep awal sistem traceability khusus untuk material proyek ini adalah membangun rancangan awal dan model traceability yang akan dipakai di PT Krakatau Engineering. Rancangan sistem traceability ini mampu merepresentasikan sumber data yang digunakan, arah arus informasi, penyimpanan data, dan sejumlah transformasi yang berkaitan dengan proses kerja yang ada dalam pengadaan material di PT Krakatau Engineering. Rancangan yang ada kemudian diimplementasikan ke dalam rancangan titik penelusuran material yang terimplementasi melalui aliran proses kerja dan informasi tiap elemen pelaku pengadaan dan pengusutan material di PT Krakatau Engineering yang terdiri atas departemen engineering, area manager, departemen procurement, departemen warehouse, dan tim site area.

2. Aplikasi perangkat lunak yang dibuat pada penelitian tugas akhir ini mengacu pada hasil dari perancangan model dinamis sistem traceability material proyek yang telah disesuaikan dengan proses bisnis di PT Krakatau Engineering. Perancangan aplikasi perangkat lunak sistem traceability material proyek dibuat untuk memungkinkan proses penelusuran material proyek serta penyimpanan database material proyek khususnya untuk material pipa dan plat baja yang nantinya dapat digunakan oleh pihak yang berwenang untuk pengadaan dan pengusutan material di PT Krakatau Engineering yaitu departemen engineering, area manager, departemen procurement, departemen warehouse, dan site area.

3. Pada proses pembuatan aplikasi software sistem traceability material proyek juga dilakukan proses validasi pada tahap akhirnya. Proses validasi berupa kuosioner dilakukan oleh pihak yang berwenang dalam proses pengadaan \& pengusutan material yaitu departemen engineering, area manager, departemen procurement, departemen warehouse, dan site area beserta project manager PT Krakatau Engineering. Hasil dari proses validasi ini nantinya akan dijadikan inputan bagi perbaikan dan pengembangan sistem traceability material proyek berupa Software Material requisition Traceability System. Implementasi dari aplikasi software ini juga dilakukan untuk mengidentifikasi benefit penggunaan Software Material requisition Traceability System yang nantinya dapat dijadikan sebagai bahan pertimbangan dalam penggunaan sistem traceability material proyek.

\section{DAFTAR PUSTAKA}

[1]. Aung \& Chang, 2014, 'An Empirical Study on Project Traceability', Journal of System \& Software, vol. 4, no. 1, pp. 178-192, dilihat 17 November 2015, http://www.sciencedirect.com/Home_Page.php

[2]. Gotel \& Finklestein, 1994, 'A System to Increase Traceability', Journal of Life Cycle Engineering, vol. 3, no. 2, pp. 62-77, dilihat 17 November 2015, http://www.sciencedirect.com/Home_Page.php

[3]. Morris, Peter W. G, \& Pinto, Jeffrey K, 2007, Project Technology, Supply Chain \& Procurement Management, $1^{\text {th }}$ ed., John Wiley \& Sons, Inc.

[4]. Pujawan, Nyoman, 2008, Supply Chain Management, $2^{\text {th }}$ ed., Penerbit Guna Widya, Surabaya. 